\title{
The Indirect Influence of Politics on Tort Liability of Public Authorities in English Law
}

Dan Priel

Osgoode Hall Law School of York University, dpriel@osgoode.yorku.ca

Source Publication:

Law and Society Review. Volume 47, Issue 1 (2013), p. 169-198.

Follow this and additional works at: https://digitalcommons.osgoode.yorku.ca/scholarly_works (c) (1) $(9)$

This work is licensed under a Creative Commons Attribution-Noncommercial-No Derivative Works 4.0 License.

\section{Recommended Citation}

Priel, Dan. "The Indirect Influence of Politics on Tort Liability of Public Authorities in English Law." Law and Society Review 47.1 (2013): 169-198.

This Article is brought to you for free and open access by the Faculty Scholarship at Osgoode Digital Commons. It has been accepted for inclusion in Articles \& Book Chapters by an authorized administrator of Osgoode Digital Commons. 


\section{REVIEW ARTICLE}

\section{Private Law: Commutative or Distributive?}

Dan Priel**

Allan Beever, Forgotten Justice: The Forms of Justice in the History of Legal and Political Theory, Oxford: Oxford University Press, 2013, xvi+325 pp, hb $£ 50.00$.

\section{THE NOSTALGICS}

Tort law, we are told, is under threat. There was a time when people understood its deep structure, its underlying logic, what it was about. Those days are now gone. Nicholas McBride described the results of this change in near apocalyptic terms: the study of tort law has undergone a ... catastrophe at some point in the twentieth century, with the result that we no longer really understand what we are talking about when we talk about tort law. ${ }^{1}$ Less ominously, others have also harked back to older times when tort law was better understood and complained how 'we', or at least 'they' (other academics, the courts), no longer understand the law. Ernest Weinrib wondered whether tort law '[has] a future'. ' John Goldberg and Benjamin Zipursky waxed sentimental for that 'domain of law that was born centuries ago with the recognition of the writ of trespassvietarmis'and wondered '[h]ow is it that academics have lost their feel for this basic legal

\footnotetext{
* Associate Professor, Osgoode Hall Law School, York University. I thank Vincent Chiao, David Howarth, and an anonymous referee for their comments. A longer version of this essay is on file with the author and will be made available online in due course. It expands on this essay in two main ways. First, I argue there that the traditional view as Beever presents it does not match legal doctrine; second, it contains an appendix that examines in detail Beever's presentation of the work of past philosophers.
} 
category?'3 Robert Stevens admitted his views on tort law were 'conservative', ${ }^{4}$ and challenged many ideas that dominated twentieth century tortlaw thinking.

Allan Beever has been part of this chorus of nostalgics for quite some time. In a book published in 2007 he told his readers that the present problem with the law of negligence is that its 'unity... has been forgotten'and that we therefore have to 'rediscover' it. ${ }^{5}$ In his new book, he extends his argument in two ways: First, it is not just the unity of negligence law that's been forgotten, but that of the entire private law; and it is not just the law that has been forgotten, but the entire form of justice that underlies it. We have come to think of the world exclusively through the lens of distributive justice, so that we no longer see that private law embodies a distinct form of justice, commutative justice. (Beever prefers 'commutative' to 'corrective' justice to highlight the fact that it is concerned not just with responses to wrongs, but with all interpersonal relations.) The source of all this is a philosophical confusion: the 'traditional' view he favours sees law (ie the natural law that exists pre-politically and that governs interpersonal relationship) as the foundation of political authority; the prevalent modern view reverses the relationship and sees all law as the product of politics (6).

This may seem like a rather abstruse debate but Beever thinks it has significant real-world ramifications: 'the modern conception leads us to misunderstand our law' (273), it made us forget 'what we ourselves know' to be true (242); it has even 'distorted our view of ourselves' (309). As an aid to failing memory, the book presents a historical account that seeks to chart the path that has led to our 
present unhappy state. Beever takes his readers on a tour through the works of some of the best known names in the history of Western philosophy with the aim of demonstrating how what 'we' once knew has become unknown. The story follows the familiar arc of rise and fall, with the traditional view getting its first articulation in ancient Athens, developing slowly until it reaches its apex in the work of Immanuel Kant. By then, however, the forces of decline have already begun to wreak havoc, and by the time we get to the present the modern view 'has become unconscious' (2); so unconscious that Beever does not expect the traditional view to 'make much sense to the reader, at least not until she has finished reading [the] book' (1). Nevertheless, it is an effort worth making, because the stakes could not be higher. The dominance of the modern view is not just of theoretical concern, it has had a terrible practical effect on our lives: it has led us to rely on the state to such a degree that we may soon unwittingly be descending towards totalitarianism (291), caring too much about the community and not enough about individuals and 'overemphasiz[ing] the importance of the state' (309).

These are very bold claims, but as I hope to show Beever does not provide anything remotely sufficient to substantiate them. The following three sections provide some of evidence to challenge Beever's claims. The next section then shows the weakness of Beever's more theoretical claims. The final section argues that contrary to Beever's claims that the traditional view provides a non-political foundation for private law, Beever's views have a clear political orientation. 


\section{THE FORGETTING THESIS}

Beever's main thesis is that there are two distinct forms of justice commutative and distributive - and that we have forgotten about commutative justice, the form of justice that governs our interpersonal relationships. Consequently, we see all law from the perspective of distributive justice, the form of justice that governs our relation to the state. As a result we do not understand the most basic features of our political or legal obligations to one another' (1). Furthermore, this perspective is 'by far the most fundamental' (2) because it is only through these interpersonal relationship that states, politics, and distributive justice become possible. The heart of the problem is that contemporary writers on 'social, political, or legal philosophy' are 'all but exclusively concerned with the state' (1). What is missing is the perspective that involves peoplein relation to each other, regardless of the state. Much of the book then proceeds to contrast what Beever believes is the correct but forgotten 'traditional view' with the prevailing but deeply flawed 'modern view'. I will call this 'the forgetting thesis'.

Part of the difficulty in evaluating the forgetting thesis is that it is so fuzzily articulated. We are told that it is 'we' who have forgotten about commutative justice, but it is never made clear who 'we' are. Sometimes it seems that it is all of us who have forgotten it, so that "[w]hen we talk of public discourse, we talk almost as if we were creatures who relate to other 
individuals only via the state and its concerns' (309). At other times, it seems that while 'we' the people actually still 'think in terms [of the traditional view] routinely' (241), 'we' the philosophers and academic lawyers have come to think in the wrong way $(14-29,255-257,173,276)$. However, even this claim is qualified when Beever admits that the view has not been 'entirely forgotten' and then provides a long list (that could have been much longer) of prominent scholars who still follow the traditional view (8). At times Beever says that merely presenting his readers with the political world through the eyes of the traditional theorists ... is no small task' because '[t]he modern view places a veil over all our thought that is very hard to lift' (6). Yet at other times Beever is confident that his readers will find ideas he associates with the modern view unintuitive (231) and even too implausible to be taken seriously' $(4, \mathrm{n} 3)$. There are times when we are told that 'the fundamental structure of the private law remains based on commutative justice' (273), but elsewhere we are told that the single-minded pursuit of the impartiality of commutative justice 'is what the common law looked like' once, but that 'it does not look like that now' (306). In some places 'casual' reflection directs us immediately to the 'obvious' traditional analysis (252), while at other times, we are told that the language of the street', presumably the casual language of the layperson, is the language of the modern conception' $(246,252)$.

Even ignoring these ambiguities, can we say that anything like the forgetting thesis is true? The answer is unequivocally negative; in fact, as a historical 
matter quite the opposite is the case. Underlying Beever's thinking is a view that insists on treating individuals as such rather than merely as elements in the collective, ${ }^{6}$ and he sees the modern view, because it obliterates interpersonal relationships, as of a piece with this collectivist approach. As it happens, historical and anthropological research strongly suggest that this individualistic ethical stance is a relative historical novelty that appeared in the world of ideas at the same historical period Beever associates with the rise of the modern view. ${ }^{7}$ In historical terms, then, Beever gets things exactly backwards.

When turning from history to contemporary reality, the view that individuals have certain obligations to each other regardless of politics or citizenship is utterly familiar. We live in a world saturated with social norms that no-one thinks of as related to the state: they range from relatively trivial matters like dress codes or the appropriate manner of addressing strangers, through matters that are on the borderline of morality like the appropriate way to behave towards one's neighbours or in a foreign country, to outright moral questions like the obligations we have towards the elderly, friends, the care for one's family and relatives and so on. It would also be wrong to think that these views are acknowledged by most people but ignored by ivory tower academics. Moral realism is a controversial (although by no means unheard of ) metaethical position, and it is standardly understood to be the view that one's basic moral obligations are universal and exist irrespective of the political unit one finds oneself in. Even without commitment to this view, virtually all the work in normative ethics is dedicated to exploring interpersonal obligations. It is for this 
reason that philosophers draw a distinction between moral and political philosophy, the former dealing with people's obligations to each other, the latter with the relationship to the state. As Beever cites titles of books on political philosophy as proof of our forgetting (195), it is perhaps worth mentioning that what is probably the most widely discussed book in moral philosophy of the last two decadesis entitled WhatWeOwe to Each Other. ${ }^{8}$

Beever, of course, knows all this. He mentions the view that '[p]olitical and legal obligations emanate in some way from the state or society, but moral obligations are or can be independent thereof' (3). To overcome this obvious response to his claim, a response he considers 'wrong' (3), Beever gerrymanders the appropriate domain for his inquiry as the 'politico-legal' (11), a term that he invents. He then discovers, unsurprisingly, that he cannot find find contemporary philosophy on interpersonal relationships. That does not show that people have forgotten their obligations to each other, only that Beever has excluded their views on such relations by definitional fiat. Even if we are ultimately convinced his classification of such relations as "politicolegal' rather than 'moral' is superior, that does not show that such interpersonal norms have been forgotten.

I doubt, however, whether Beever's novel classification is superior. Beever suggests two ways of distinguishing politico-legal norms from 'mere moral'ones. At one point he says that 'morality is focused on individuals as such' (3) rather than their relations with others. That is, to put it gently, a rather unusual definition of morality as it excludes virtually everything that most people talk 
about when they talk of morality. To get a sense of how peculiar this definition is, it leads Beever to say that 'it would be odd to think that [the reason I should not hit my wife] was moral rather than political' (4), which I am confident is the exact opposite of how most people would think about the matter.

At a different point Beever offers a more functional distinction between the two kinds of norms, in that 'only [politico-legal] norms justify coercion' (31, also 20). This claim, as far as I can tell, is indirectly related to the claim that politico-legal norms are concerned with the right, while mere moral ones are concerned with 'the good' and with 'moral worth' (31). This claim has the curious implication that Beever's politico-legal norms are, as a conceptual matter, tied to the state, because as a conceptual matter they justify coercion. This is not true of the view of modern thinkers for whom the question of which norms are the business of the state is itself a normative question (with some thinking that promoting the good is the business of states, others rejecting this view). Even if we put the entire domain of 'mere morality' to one side, Beever's thesis still bears no relation to reality. Though he has some reservations about the term, Beever clearly aligns himself with natural law theory (eg, 9-10, 123-125). If what has been forgotten is some version of natural law, then the forgotten thesis is false. A quick and unscientific search for English-language books with the term 'natural law' in their title published since the year 2000 returned dozens of such books. ${ }^{9}$ This is not to say that natural law theories have not changed through the ages or that there are no important differences among them. The point is that at the level of abstraction at which Beever addresses these issues, the 
ideas he talks about are a familiar part of the discourse.

The picture does not change when we consider Beever's more specific theses. Beever's main claim in political philosophy is that (natural law) norms of interpersonal relations are the basis for politics; his main thesis in legal theory is that these pre-political norms form the foundations of private law. Beever presents the first thesis as something that most of his readers will find utterly baffling, indeed barely comprehensible. As we have all been looking at the world through 'the modern theorist's glasses', 'we have as yet no idea what the world would look like without them'. Once we took them off we would be able to see 'vistas few today imagine' (33). If by 'us'Beever refers to the general public, he may be right, because the questions he is interested in belong to a rarefied academic debate that most people do not bother themselves with one way or the other. But if we consider the target audience of this charge, that of political philosophers, the supposedly forgotten view that bases the justification of political institutions on interpersonal moral foundations is entirely familiar, and not just among those who see themselves as working within the natural law tradition. ${ }^{10}$

The same is true of Beever's claims regarding private law. Charles Fried's Contract as Promise, a book that argues that one can explain almost all of contract law in terms of promissory relations that exist between individuals outside the state, is not exactly an obscure book. In it, Fried rejects the view that justifies contract law for its ability to promote 'a distinct collective policy, the furtherance of economic exchange'. ${ }^{11}$ Fried argues instead that contract is based on the 
binding force of an exchange of promises, which he thinks is 'grounded not in arguments of utility but in respect for individual autonomy and in trust'. ${ }^{12}$ Nor is Fried's the only attempt to explain contracts in terms of promises or other interpersonal relations. The same goes for tort law, where just in the last few years we have seen works with titles such as Torts and Rights and Torts as Wrongs' which espouse the supposedly forgotten view. Beever may have some disagreement over particulars with any of these scholars, but the key components of such views are exactly those he claims are now virtually forgotten. And while these views are by no means universally accepted, they are familiar and widely discussed. Similar views have also been popular in criminal law. Despite the prominence of the state in the present-day criminal justice system (as prosecutor, adjudicator, and enforcer), much of the resurgence of retributive theories of punishment has been attributed exactly to the view that sees criminal law as concerned with wrongs committed towards others (cf 87-88) and which sees criminal law's underlying theory as belonging to moral, not political, philosophy. Here too, the ideas in question are controversial, but the suggestion that they are somehow forgotten is absurd. ${ }^{13}$

Nor are such ideas merely the domain of academic debate. Some of the most discussed ideas in the moral theory of our day have counterparts in social activism and political reform. Global justice, universal human rights, and concern for animal welfare (to name but a few) are all theoretical ideas with real-world counterparts, all largely based on the idea that people have obligations to others outside the state. Contrary to Beever's claims, one of the distinctive marks of the 
modern age is what Peter Singer called the expanding circle', the broadening of the domain of obligation people think they owe to others (including non-humans) despite not having any relation (personal, familial, or national) to them. ${ }^{14}$ To an unprecedented degree, ours is the age in which people have concerned themselves, without any mediation by the state, with the lives of strangers.

\section{MISTAKEN HISTORY}

As mentioned at the outset, Beever seeks to bolster his claim about our present forgetting of commutative justice with a historical narrative. As the claim underlying the history is false, it is no surprise that the narrative aiming to show how we got here cannot support it. It would take more space than I have here to demonstrate just how inaccurately Beever presents the theorists he considers. Suffice it to say that whenever I checked the views Beever attributed to a philosopher against what that philosopher actually wrote, I found major discrepancies. ${ }^{15}$ I limit myself here to the person Beever claims has made the single most significant contribution to the displacement of the traditional view, Thomas Hobbes.

According to Beever, the English Civil War 'had an enormous effect on [Hobbes's] thought ... [which] helps us explain the form of Hobbes' theory' (175) (never mind that Hobbes first expressed his ideas in The Elements of Law, which was written before the Civil War erupted). Beever explains that 
Hobbes became convinced that 'the ultimate cause of the English Civil War was the idea of a higher law' (179) (never mind that in Hobbes's book on the Civil War, which Beever does not mention, it is not 'the idea of a higher law' that troubled Hobbes, but that of divided authority to determine what the higher law means). ${ }^{16}$ According to Beever the effect of Hobbes's ideas was destructive. They 'blinded us to more accurate views of [the political and legal world]' and 'we have become so accustomed to our partial sight, that it is only with great effort and after much squinting that we are able to open our eyes' (195).

This claim is very difficult to square with Beever's own reading of Hobbes's work. Beever argues that Hobbes 'rejects the tradition without any justification at all' (202); not only that, despite his efforts to depart from the traditional view, 'Hobbes [was] committed to the existence of commutative justice and to the notion that it grounds all politico-legal obligation' (201-202). So according to Beever himself, Hobbes does not give any reason for departing from the traditional view, and then does not actually depart from it! If this is so, it is not clear why Hobbes should have been so 'influential' (202). The errors Beever attributes to Hobbes are not matters discovered only after close analysis of Hobbes's arguments (something Beever never attempts to do); these are glaring blunders of a philosophical novice. Put slightly differently, if, as Beever suggests, Hobbes relied on the traditional view he supposedly repudiated, how did he 'ma[k]e people see the world in a different way' (195)? Even supposing we moderns cannot see those errors as our vision has become so clouded, 
Hobbes's contemporaries, at the time not yet exposed to the modern view, should have spotted them immediately. On Beever's retelling, rather than being an epoch-making figure, Hobbes should have been a minor figure in the history of thought, rarely read and remembered only by a few historians. ${ }^{17}$

Furthermore, Beever's story does not match the historical record. After his death Hobbes was often known as 'the Monster of Malmesbury', someone whose books contained dangerous heresies, not an influential figure whose ideas were embraced. It is therefore difficult to see the historical basis for Beever's claim that by the time Locke published his Two Treatises of Government the traditional view in England had already 'collapse[d]' (224) to such a degree that Locke could no longer even talk of commutative justice. Indeed, even today when Hobbes is widely read and often admired, he remains in many respects a notorious thinker. No matter how 'influential' he has been, Hobbes's readers have retained their critical faculties to such a degree that they have been able to reject what Hobbes must have considered his most important conclusion - the necessity of an unbounded political authority for the sake of social stability. Another problem with Beever's account is that even after Hobbes (and Bentham, and Rawls) 'we' have not stopped reading others. One of the most puzzling aspects of the forgetting thesis is that the thinkers Beever hails as the beacons of Truth are among the best known thinkers in history, philosophers whose place in the canon of Western philosophy could not be more secure. His list of traditionalists includes Aristotle, Aquinas, and Kant, who are still read, debated, analysed, taught, as well as criticised. No matter how 'influential' 
Hobbes has been, the suggestion that the ideas of Beever's traditionalists have been forgotten is indefensible.

\section{MISSING HISTORY}

So far I have discussed what is in Beever's book, but it is worth spending some time on what is not; what, if you wish, Beever has forgotten. One of the striking features of Forgotten Justice is the limited extent to which the thinkers discussed in it are placed in their historical context. To the extent that they are, the only history Beever deems relevant is the history of kings and queens, of war and peace $(37-38,61-62,90-91,95-98,175-178,207-208) .{ }^{18}$ This leads to some rather odd historical claims, as when Beever claims that Aquinas, Pufendorf, and Kant were all 'heavily influenced by the Holy Roman Empire' (96). What is completely missing (rather surprisingly, in a book that aims to highlight the importance of interpersonal relationships beyond the state) is social, cultural, and technological history. So we read about the Glorious Revolution (208) but not a word about the industrial revolution, despite the latter's much greater impact on the shape of present-day private law; we read about the French revolution (203) but not about the scientific revolution, despite the fact that one cannot understand modernists like Hobbes or Bentham without taking into account the way they, explicitly and consciously, have sought to extend the methods of natural science to human affairs.

One gets only the briefest of hints from Beever's book of the fact that the 
modern states in the developed world are different beasts from those that existed in the times of Locke, Kant, or even Mill (to say nothing of Aristotle or Cicero). Beever only acknowledges this at one point when he says that Aquinas, Pufendorf, and even Kant lived at a time in which the centrality of the state... would have seemed highly questionable, if not strange' (98), but he does not draw from this the conclusion, that at least as a descriptive matter it is the modern view that corresponds to present-day political reality. Consequently, it is not 'modern theorists [who] have adopted an understanding of the political and the legal that is fundamentally wrong' (1), but traditionalists like him who claim we would get a better grasp of the politico-legal reality of our time by reading works written by people living in, and writing against the background of, an entirely different political environment.

Because Beever is not alone among contemporary traditionalists in ignoring this broader historical context, it is worth relaying it in slightly greater detail. In the supposed glory days of respect for interpersonal relationships, when the state and distributive justice were (at best) only a remote presence in most people's lives, what one finds is not so much respect for interpersonal relationships, but levels of interpersonal violence dramatically higher than those found in developed countries today. To this day, non-state societies have average homicide rates that are orders of magnitude higher than those found in state societies; and the same is true of Western societies in the pre-modern age. For instance, the homicide rate in fourteenth century Oxford was more than a hundred times higher than the homicide rate in contemporary London. ${ }^{19}$ In 
today's western countries, where the state is most prominent, women more than half the world's population - enjoy more interpersonal independence' (292) than they have had at any point in recorded history. ${ }^{20}$ Many attribute these dramatic changes, at least in part, to the rise of the modern state. ${ }^{21}$ Though it is difficult to be certain about causality on such matters, at the very least the data suggest that individuals' concern for interpersonal relations alone may not be powerful enough to guarantee people's safety from others. They also undermine the suggestion that because of an ever-present Leviathan we have collectively forgotten about interpersonal relations.

It is also worth remembering that although the state is in some respects a more prominent feature in our lives these days, it is much less so in others. Jeremy Bentham, a modernist according to Beever, was among the first to call for decriminalising sexual 'irregularities' in the name 'all comprehensive freedom'. Immanuel Kant, probably Beever's foremost traditionalist, believed that it is the state's business to punish these violations of natural law. ${ }^{22}$ Here is what Bentham had to say of the idea of criminalising certain sexual practices: "If there is one idea more ridiculous than another, it is that of a legislator who, when a man and a woman are agreed about a business of this sort, thrusts himself in between them, examining situations, regulating times and prescribing modes and postures'. ${ }^{23}$ Beever's account makes it hard to understand why such words sound so obvious to modern ears.

The history of scientific and technological development is also forgotten in 
the works of the nostalgics. Beever manages to write a book tracking the historical development of contemporary ideas on private law without mentioning the fact that these days (but not in the days of Locke or Kant) most adults in many parts of the world are in charge of machines that can cause death or serious injury to others, not because of forgetfulness of the importance of interpersonal relationship, but due to a moment's carelessness. Those who lament the supposedly skewed contemporary vision of tort law as 'accidentlaw-plus', ${ }^{24}$ forget that it reflects modern-day reality: much less interpersonal violence than in the olden days of assaultand battery, but many moreaccidents.

Even limiting ourselves to the world of ideas, Beever forgets that we live in the world of risk and probability, theoretical concepts largely unknown before the eighteenth century, but now so prevalent we no longer notice their ubiquity. The development of notions of risk is not just the product of mathematical advances, but also due to the wealth of statistical data that makes risk assessments possible. (The word 'statistics' bears witness to this science's historical connection to the rise of the state.) The methodical collection of such data, though it had some predecessors, began in earnest only in the nineteenth century. ${ }^{25}$ Consequently, in its modern sense 'risk', contrary to Cardozo's famous words in Palsgraf v Long Island Railroad, is not 'a term of relation"26 but one of pooling different people (and events) together.

As none of this makes it to Beever's story, we are left puzzled when we read that the traditional view declined 'after the convulsion set off by Hobbes and the English Civil War' (6), especially as Beever himself says that this 'decline was not 
the result of a confrontation between the traditional and the modern view won by the latter', but rather the result of a "paradigm shift" in the way that people thought about politics' (6). Thomas Kuhn, who coined the term, argued that paradigm shifts occur when there is an accumulation of empirical findings that cannot not be explained within an existing scientific paradigm. ${ }^{27}$ Obviously, by using Kuhn's term, Beever is not obliged to accept Kuhn's analysis of it, but as he denies anything like this was the cause of the paradigm shift in this case, he needs to supply an alternative explanation. This is no small matter. The forgetting thesis is the central thesis of Beever's book, and if it were true, it would count as one of the most dramatic transformations in human (intellectual) history. How did we come to forget our interpersonal relationships? The two culprits Beever mentions just won't do: on Beever's account blaming Hobbes, as we have seen, makes no sense; as for the Civil War, apart from its supposed influence on Hobbes, it is unclear what, if anything, it had to do with the decline of the traditional view.

As the forgetting thesis is false, we need not trouble ourselves too much with this question. The broader historical canvas, however, suggests an alternative story that provides part of the explanation of the state of contemporary private law. This story is not about forgetting of interpersonal relations, but of remembering the world we live in and adapting the law to an environment radically different from what it had been three centuries ago. It is true that private law changed by taking broader social considerations into account, but this happened not because people have forgotten about interpersonal relationships. 
It is because, rightly or wrongly, those in charge of the development of private law have come to see (sometimes only semi-consciously) that private law would function less well than other alternatives in the circumstances of the modern world, if it maintained its 'traditional' form. In part, change was necessary because the environment and society that the law had to deal with were very different than before; in part, it was needed because lawmakers had more information and better institutional tools available to them that could be harnessed for improving the law. And as the pace of these developments social, political, scientific, technological, demographic - has dramatically accelerated in recent times, it should not be surprising that ideas or doctrines that may have served people reasonably well from Aristotle to Locke, became obsolete (or at least in need of updating) within a fairly short time.

\section{BEEVER'S THEORETICAL CLAIMS}

I have spent considerable space on Beever's historical thesis, because it is the central idea animating his book and it takes up more than two-thirds of it. Those sympathetic to Beever's position could still maintain that one can reject his forgetting thesis and ignore his historical narrative and still believe that private law is better understood in terms of commutative justice than in terms of distributive justice. This is unquestionably true. It is therefore necessary to examine the traditional view on its own terms. In this section I will largely ignore 
Beever's historical narrative and examine Beever's claims regarding the problems with the modern understanding of private law. I will argue that Beever does not provide any good reason to favour of the traditional view and that he fundamentally misunderstands the modern view. ${ }^{28} \mathrm{I}$ have divided the discussion into three somewhat overlapping topics: the supposed conceptual claim about the nature of private law; the role of private law institutions; and Beever's neglect of the implications of his own traditional view.

\section{The conceptual claim}

Behind Beever's historical narrative, lies what he considers is a conceptual point (308): Beever seeks to convince his readers that there are two distinct forms of justice, each with its own domain and neither reducible to the other. He seems to think that by pointing out that a form of justice 'exists' and that it matches a certain practice, he has done enough to show that that practice is better understood in terms of that form of justice, and that it would be wrong to conceive of it differently. For example, he says, "[Aristotle's] claim is ... that corrective justice ought to be done because corrective justice demands it. That is what it means for corrective justice to be a form of justice' (73). The contextleaves no doubt that Beever shares this view.

This passage raises an intriguing question that Beever never carefully addresses, which touches on the relationship between commutative and distributive justice. This may seem like a borderline question that need not affect the 'internal' analysis 
of the 'nature' of commutative justice, but as I hope to show it is central to the evaluation of Beever's position. One possible way of understanding the relationship between commutative and distributive justice is that they occupy (to borrow a phrase from Stephen Jay Gould) two 'non-overlapping magisteria'. We can classify events in the world as belonging exclusively to commutative justice or to distributive justice (and probably some that fit neither), but no event raises questions for both. It follows from this view that there can be no conflicts between commutative and distributive justice. (There is, I think, some reason to think that this is how Aristotle understood the relationship between the two, but I will say nothing here to substantiate this claim.)

In someinstances itlooks as though Beever believes that this is the correct view. For example, it fits his view that limits distributive justice to redistribution (279). In a different (and perhaps inconsistent) formulation he says that an act constitutes 'distributive injustice only if the reason it is wrongful is that it results in an unfair distribution of benefits and burdens amongst the community' (107-108, also 137, cf 145). On this view, it seems, distributive justice is not about the redistribution of resources. On this view distributive justice is about what individuals should be asked to contribute (burdens) for the sake of certain public goods (benefits). That is an inegalitarian conception of distributive justice, which needs to be backed by a normative argument, not presented as a conceptual truth. ${ }^{29}$

Even if this view is correct, it still has to address the fundamental problem of explaining property (and by implication property law) exclusively in terms of commutative justice. Beever himself thinks of property as 'relationship to things' 
(205) which bind the whole world (as opposed to the rights against other people in the rest of private law). Beever's defence of this view amounts to the claim that the rules [of property law] do not refer to issues of distributive justice and ... they are oblivious to distributive outcomes'(146). Even if true (and that is, in fact, a very contentious claim), this response does not address the problem, which is that because property rights impose limits on all others, they cannot be grounded only in interpersonal relations, because no human has interpersonal relations with all other humans. The charge is that for this reason property requires political institutions that create rights that bind everyone (whether or not the resulting property regime is 'oblivious to distributive outcomes'). As Beever acknowledges, something like this view can be found even in the works of traditionalists Pufendorfand Kant $(137,161)$.

A second problem, seemingly more technical but no less significant, is that Beever does not hint at what happens to property upon the death of its owner, at least when she died intestate. Do rules of inheritance belong to commutative or distributive justice? As death does not (necessarily) involve a bilateral relationship, it is hard to see how commutative justice could be relevant, and it is not part of Beever's own statement on the scope of commutative justice (205). If so, then Beever is wrong to say that commutative justice alone suffices for governing property. Even if inheritance is somehow included in commutative justice, what does it say about it? Does private property return to the commons upon death (in which case positive law does not merely enforce commutative justice but 
changes it), or does it automatically become the private property of other people $?^{30}$ Does it call for primogeniture? ${ }^{31}$ Can commutative justice tell us how much the spouse should get in relation to the children? Should males and females have equal shares? (A negative answer to this question seemed as obvious to many of Beever's traditionalists as an affirmative one was obvious to moderns like Bentham or Mill, to say nothing of those who came after them.) Is the property held jointly by all successors, or does each get an exclusive ownership in a share? If it is the latter, what is the standard for division: equal shares per person, or some other measure (eg, the amount of love and affection each relevant person had bestowed on the deceased)? Who are the relevant persons for shares: is it limited to one's family, or do loving friends get a stake as well, perhaps even prior to ungenerous children? As death, alas, has happened a few billions times in the course of human history, these questions can hardly be brushed aside as quibbles over trifles.

All this does not bode well for Beever's overall point, which is that private law is not about "the way of life of the peoples"' (205, quoting and rejecting Montesquieu). The different answers that can be (and have been) given to the questions posed above about inheritance are examples of the role of social values in private law. Even within the core of private law that Beever talks about, how are we to think of the old rule that women (largely) lost their capacity to enter into contracts upon getting married? How are we to think of changes in the way property law has treated marital property during their relationship and upon its 
dissolution, of what belongs to the things' that according to Beever property law is about (205), or of harms are recognised by tort law? On Beever's view the only way to explain such changes is as the correction of some conceptual error about the nature of private law. I think a more natural way to think them of them is as reflecting 'the way of life of the peoples'. How are we to decide between these competing explanations? If changes in private law had been the result of 'conceptual' errors and had nothing to do with prevailing social views, we would have expected to see no correlation between changes in private law and changes in social attitudes. But of course that is precisely what we do not find. In all the examples I gave (and in many others I did not) changes in private law and in socialattitudes have been in tune.

For such reasons the non-overlapping magisteria view looks like a dead-end, and at times Beever himself seems to have a different understanding of the relationship between commutative and distributive justice. He acknowledges that commutative justice may have political (305) and distributive (166-167) consequences. Now, if this is the case and if (as Beever thinks) commutative and distributive justice are distinct forms of justice irreducible to the other, then necessarily there will be conflicts between them, ie cases in which following commutative justice will have effects that make matters distributively worse. Beever's view amounts to the claim that in all such conflicts, we should follow commutative justice, but since there is nothing in Beever's book that directly addresses this question, he offers no reason to think that in any (let alone every) case of conflict, we should prefer commutative to distributive justice. 
Here is another way of making this point: a lawmaking body can fully accept Beever's way of dividing commutative and distributive justice and simply treat the kind of events we classify under 'private law' exclusively on the basis of distributive justice standards. It is plainly not impossible to do so - New Zealand's accident scheme is an example of doing just that. But if ignoring commutative justice altogether is conceptually possible, then clearly taking it into account alongside other considerations is conceptually possible as well. This may be undesirable, but there is no conceptual difficulty with doing so. If Beever is troubled that the resulting legal regime is not 'genuine' tort law, so be it: we'll call it schmort law; and if such a position is not 'genuinely liberal'(292), so be it: it can be genuinely schliberal. What matters is if it is overall better, not whether it fits a label.

The picture gets even more complex once it is acknowledged that virtually all modern states routinely use what in Beever's terms are commutative justice events for the sake of promoting distributive goals: in many states, most sales (commutative justice events) are an occasion for the collection of tax (a distributive justice event); the same is true of income for labour, which Beever treats as a clear example of commutative justice (279). If such taxation is unobjectionable (and Beever says nothing to the contrary), there is no principled reason why a negligence case (a commutative justice event) should not also be an occasion for distributive justice. There may be normative considerations against doing so, but there is nothing in the conceptual analysis of private law or of commutative justice that bears on the question 
whether courts should do so. For even if we accept such conceptual arguments, all they amount to is that such considerations do not 'belong' in tort law (which 'genuinely' is exclusively about commutative justice). In response we could just say that tort law events require courts to take into account commutative justice considerations (as found in tort law, strictly so-called) alongside distributive ones.

\section{The institutional argument}

All this shows the pointlessness of trying to win normative debates by appeal to conceptual analysis. Sensing perhaps the weakness of these conceptual arguments, Beever bolsters his normative conclusions with arguments relying on the institutional limits of courts and their lack of legitimacy to decide political questions. So understood, there is nothing in any event that forecloses taking distributive considerations into account, but there are constraints on the body that decides such cases, that limit the sort of considerations it should rely on.

Unlike the conceptual arguments, these are valid concerns, but they need to be considered carefully. One reason to doubt such arguments is that they prove too much. If such arguments were convincing, they would require a significant change in the way courts have operated for several decades now in the domain of public law. Even if Beever is interested only in private law, it is surprising, to say the least, that he does not acknowledge the full scope of his arguments and 
the extent to which they would require not just some rethinking in private law, but also rolling back decades of public law developments as well. Simply as a matter of sheer numbers, if it is institutional capacity and political legitimacy he is concerned about, the role courts often play in constitutional litigation should have worried him much more. ${ }^{32}$

Beever might reply that he is happy (or sad) to report that in his view much of public law adjudication is politically illegitimate but that, unlike the lost cause that is public law, in private law there may still be hope in returning the law to its proper, traditional, origins. But even within the domain of private law, it is unclear whether courts could satisfy his strictures. Beever's argument, a familiar point in the work of tort law nostalgics, is that when the court decides an issue according to commutative justice it is able to determine how the gap should be filled by considering justice as between the parties', hence its law-making need not be political' (302). Notice first how Beever changes his analysis to fit his desired conclusion: earlier in the book Beever designated private law and commutative justice to what he called the 'politico-legal' domain. By the end of the book, in addressing a different question, the boundaries are redrawn so that private law is no longer political. In any case, even if private law is by some measure completely non-political, Beever's conclusion does not follow. The institutional concerns about judges deciding political matters is not due to the fact that there is some category of 'political' questions that judges are inherently forbidden to consider; the concern is with having them decide questions with certain characteristics that make them (according to this line of reasoning) 
inappropriate for judges to decide. If decisions in other domains have similar characteristics, they are equally problematic, even if they are not 'political'. (In truth, since there is no preordained list of 'political' matters, we are likely to consider a matter 'political' if it has these characteristics.) Questions raise similar concerns for institutional capacity and legitimacy when the following three conditions obtain: the question relates to matters affecting the life of large numbers of members of a community; the answers are controversial among members of the public; and there are no deemed experts capable of deciding them 'correctly'. Whether or not classified as 'political', questions about the scope of liability in private law often meet these criteria.

Beever concedes that there may be disagreements on questions of private law (302) but denies that this fact undermines judges' capacity to decide them (304). But why should such matters be handed to judges even if they may be publicly controversial? Beever's answer is that judges have superior expertise with respect to commutative justice' (306). In other words, he thinks that the last of the three characteristics identified above for institutionally problematic decisions does not obtain. But judges' expertise on commutative justice is an empirical claim for which he gives no evidence, and it is unclear what would make them such experts. It is not as if there is some sort of certification or specialisation that can show one to be an expert on commutativejustice in the way one can be shown to be an expert on the rules of contract law, and to argue that judges' expertise in contract law makes them experts in commutative justice is precisely what Beever needs to show. It cannot simply be the fact that because judges are 
required to think about commutative justice they have developed expertise on the subject, for if that were the case, we could just expose judges to the broader range of issues required to make good decisions on distributive justice and thus make them experts on political questions. In fact, if constant exposure to a question is sufficient for such expertise, arguably contemporary judges could claim expertise in distributive justice already since public law litigation constantly exposes them to it. Even if it can be shown that judges are experts on commutative justice because legal doctrine embodies it, that would just beg the question why doctrine should match commutative justice (and not something else). Since it is possible to decide such questions on other grounds, if most members of a community prefer a different legal rule which they justify on (say) distributive justice grounds, why should they not get to enact it? Finally, if Beever's forgetting thesis is correct, we should be sceptical of the alleged judicial expertise on questions of commutative justice. After all, it is the judges who have been encumbered by politics in the domain of public law and who have often blurred the boundaries between the two; it is the judges who read those academic articles peddling the modern ideas. The people, by contrast, are according to Beever himself, less exposed to such dangerous nonsense, and so (either directly or through their elected representatives) should be given to decide these matters.

This shows that even if we accept Beever's argument wholesale, all that follows is that judges should decide cases on commutative justice grounds if we wish to have such cases decided on non-political grounds. Society could prefer to have 
such cases decided politically and designate it to a non-judicial body that would be empowered to decide such cases on distributive grounds. Beever does not directly address this question but some remarks he makes reveal his attitude to such suggestions. One option is to turn these matters over to the legislature which (if functioning properly) avoids both the problem of legitimacy and the problem of lack of institutional capacity. Nevertheless, Beever believes that when the legislature intervenes in the domain of private law, its role should be limited to 'remov[ing] obstacles to the achievement of commutative justice' (306). This view does not follow from anything Beever has argued for. One may accept that there are some pre-political natural law norms; one may even grant that some such norms are necessary for establishing a political community so that in some sense some law is prior to politics. It does not follow that after the polity's establishment, it should simply try to enforce these pre-political norms to govern the interpersonal relationships that exist within a political community. The legislature may choose to do that, but it may equally decide to replace them with others. To deny this is tantamount to the claim that there are substantive limits on the law-making powers not just of courts, but also of legislatures, which go beyond anything that may be written in any constitution. (This implies that according to Beever himself, courts and legislatures lack political authority in this field: 215, cf 178.) But nothing, either in the conceptual 'nature' of private law, or in the traditional view's priority of law over politics warrants this conclusion. Once we abandon the non-overlapping magisteria view, distributive justice considerations do not miraculously lose their validity in the context of a 
commutative justice event, and a legislature may enact laws that reflect that.

Beever strongly disapproves of such ideas. He considers the possibility of appointing 'social policy expert[s]' (300) to an administrative body that would decide such cases on the basis of distributive justice, but finds such a solution would be 'repellent' and 'unjust' (300). But what if these policy experts were to give their recommendations that would then be enacted by the legislature, leaving judges with politically unproblematic task of applying these rules, where is the problem? I speculate that he considers such a solution 'unjust' because it would not comply with the principles of commutative justice. But, to the extent that commutative and distributive justice may conflict, entrusting courts to decide such cases on the basis of commutative justice would also be unjust, distributively unjust. In such a case, the only question is whether society prefers commutative injustice to distributive injustice or vice versa, but on this view, eitherway therewill be an injustice. Without further argument there is no reason to prefer one sort of injustice over another.

And why is such a suggestion 'repellent'? Courts are, on Beever's view, a kind of administrative body staffed by commutative justice experts, so what is the problem with appointing experts on distributive justice and enacting their recommendations (leaving decisions to judges based on legislative rules promoting distributive justice), or even turning the entire matter for distributive experts to decide? I believe Beever's visceral reaction to such a solution tells us something about his views on distributive justice, namely that he doubts there is any expertise in the domain of distributive justice, that, at least in the sense 
used in contemporary political theory, it is just a fancy name for a free-for-all fight for a larger share of society's resources. Administrators placed to decide such matters would be 'repellent' because they would inevitably impose their own preferences and prejudices. As a result, this solution would be a form of tyranny with the power to take property from some and give it to others. By contrast, I suspect Beever believes commutative justice is a product of Reason, a domain on which one can have a rational debate. I cannot be sure that this is Beever's view, but much of what he says fits it, as does what he does not say: there is no real discussion in the book of what Beever thinks the proper domain of distributive justice is, and more importantly, there is no attempt to articulate, even in general outline, some way of resolving conflicts between distributive and commutative justice.

The practical effect of Beever's view is that certain events will be decided on the basis of commutative justice alone. Beever seems to think that this follows from the fact that courts are institutionally-constrained, but in fact in such cases we face a choice. If we are convinced that certain events raise both commutative and distributive justice considerations (which seems to be Beever's view) and that judges are institutionally incapable of deciding such matters taking into account all the relevant considerations, then the institutional question is this: should we leave the decision to a body that is not going to take all relevant considerations into account (thus more-or-less guaranteeing its decisions will be all-thingsconsidered wrong), or should we remove the decision from that body and giving it to a different one that can take all considerations into account. There is no 
obvious answer to this question, for the benefits from awarding the decision to bodies that decide on narrower grounds (simplicity, fewer controversies) may outweigh the benefits from deciding based on all the relevant considerations. But such a question, if taken seriously, requires careful consideration. The view that it would always be better to give decision-making power on such matters to the more institutionally-constrained body without any argument seems motivated by different concerns, political ones. As I will argue below, Beever's book reveals his political preferences, and the priority he gives to commutative justice in cases of conflict matches those preferences.

\section{The missing alternative}

So far this section ignored history, but it is worth returning to the broader historical picture presented earlier for an alternative understanding of commutative justice. On this alternative view commutative justice is not a distinct form of justice but a distinct form of regulation. Its two most important distinguishing characteristics are after-the-fact response to claims brought about by individuals. (This is easiest to understand with regard to tort law, but it is true of other branches of private law as well.) These features are the main reason why this form of regulation was until fairly recently (by and large) the only form of regulation available, why, in other words, it seems to correspond to a 'traditional'view of the law: it is typically the simplest form of regulation. Once technology opened up new possibilities, it became possible to think of new ways 
of regulating many of the events previously regulated by commutative justice.

I offer the characterisation of commutative justice as a form of regulation as a competing understanding to Beever's. The question now is which of these two interpretive possibilities better explains and illuminates our practices. Though plainly this is not a matter that can be explored here in any detail, I believe the historical evidence briefly sketched earlier supports the view that regards what is known as 'commutative justice' as a form of regulation. Many puzzles about commutative justice and its relationship with distributive justice are resolved once we understand it in this way.

Beever's ignoring this possibility may explain why he says nothing about another regulatory possibility, one that he should have found particularly attractive, a more 'genuinely' private version of private law than the one he discusses. People can make agreements and rely exclusively on their sense of the binding force of promises (or whatever) as the reason to abide by them; people can accept a pre-political obligation to repair harms (or wrongs) they cause others by making amends in the form of monetary compensation, public apologies, or in any other form. So long as the state does not interfere with such actions, this form of 'private law' would be a much better example of commutative justice (in its purely interpersonal, bilateral sense) than the one governed by state institutions. (Admittedly, part of the reason why people fulfil their contractual obligations or agree to pay compensation in such cases may have to do with their concern for their reputation in the eyes of third parties. Still, the state would not be involved.) If Beever is concerned for the 
preservation of interpersonal relations, he should have argued for this, at least as an ideal to aspire to. After all, even if state courts strictly limit themselves to commutative justice and to enforcing people's pre-political rights, in playing an active role in enforcing such rights they may plant in people's minds what Beever considers the bane of our modern existence, the tendency to 'overemphasize the importance of the state and overestimate its ability to facilitate justice' (309). In other words, if Beever really is troubled by the state and the dangerous role it has come to play in our lives, if he really is concerned for our interpersonal freedoms being crushed by the state, it is odd that he never considers the removal of the state from private law. This is no mere libertarian utopianism: There are some writers who have written admiringly on examples of this more private form of regulation. ${ }^{33}$

To those less troubled by the presence of the state in their lives, such studies, though valuable, highlight (perhaps inadvertently) the limits of this form of regulation: First, they typically work only among fairly close-knit or small groups where informal mechanisms for enforcing compliance can function well. Whenever these conditions are not in place, one inevitably finds complex institutional mechanisms that supplement (rather than merely enforce) prepolitical private law. ${ }^{34}$ Online markets function as well as they do because of sophisticated trading platforms (provided by a third party that sets up the rules and as such fulfils a similar role to the state) that can facilitate the trust that would otherwise be difficult to maintain among strangers. Second, such forms of 'opting out' piggyback on the state. The historical evidence mentioned earlier, 
as well as contemporary data on countries with weak political institutions, strongly suggest that peaceful mechanisms that allow neighbours to settle their disputes without law, are easier to sustain when a state with well-functioning institutions exists in the background.

Recognition of the conceptual possibility of a form of regulation more private than the one Beever discusses also makes it easier to understand why, when the state is involved, there is no basis for limiting a priori the kind of considerations it can bring to bear in adjudication. Those who manage their affairs on their own can decide on whatever rules fit their fancy; when the state is involved by providing a set of enforceable rules (ie, when the state mobilises its power to guarantee others' compliance), it provides a service needed precisely by those who worry that the truly private form of private law would not suffice. Two points follow: first, there is nothing odd about the idea that on this view 'contract law is seen as an imposition on freedom rather than the realisation thereof' (270), for that is precisely what contract law is for: it is an institution that brings in a third party - the state - to compel (or guarantee or signal) compliance. ${ }^{35}$ As such, contract law can be seen as an imposition on freedom for the sake of the (greater) freedom made possible by contracting. Second, and more important, because positive private law is a state-provided service, the state is entitled to provide it on its own terms, which may include (amongst other things) taking societal or distributive considerations into account. That is exactly what the state does when, as a matter of unquestionable legal doctrine, it refuses to provide its assistance to the enforcement of certain 
contracts that are unimpeachable from a purely commutative perspective. Those unhappy with this service, can (and do) resort to other, more private means of enforcement: Knowing that the state will not provide its enforcement-services for his agreements is why the contract killer relies on other meansfor making sure he is paid.

\section{BEEVER'S POLITICS}

Beever's arguments fail as an attempt at 'understanding' the law and politics of our times, because he ignores almost everything that is relevant for understanding them. What he is unhappy about is not the prevalence of an 'idea' (2), it is the reality built on the foundations of this idea. If we are to make sense of the book, it is not as an attempt at understanding, but as a work of political advocacy. This seems to be a latent theme in the book (eg, 104) mostly hidden under a veneer of conceptual analysis. It is only in the final pages of the book, as though Beever could no longer contain himself, that his politics become explicit. Beever suggests that the modern view leads to totalitarianism (289-291). To demonstrate just how far we have already gone down that road, in an essay published shortly before Forgotten Justice and which can be read as a précis for it, Beever has noted that ours is the age of 'human resources' as proof of the manner in which the modern view has made us treat our fellow humans. ${ }^{36}$ In that essay Beever candidly said he hoped his ideas would be politically transformative ${ }^{37}$ and for that end in Forgotten Justice he quotes from Joseph 
Goebbels and from Che Guevara (290-291, 308-309) as warning signs for where we are headed, the impending eradication of the individual under the crushing yoke of an allconsuming state. ${ }^{38}$ It is not just the future, though: already 'our forgetting of commutative justice' has 'led us to ignore the importance of interpersonal freedom, to overplay the needs of the community vis-à-vis the autonomy of the individual, and to overemphasize the importance of the state and overestimate its ability to facilitate justice'(309). In the same vein, in the earlier essay Beever also said that '[h]uman rights law is the ambulance at the bottom of the cliff. We need it in part because the fence at the top, constructed in no small part by the private law, has been torn down. But it is worse than this, as that law now encourages people to fall down'. ${ }^{39}$

Though Beever seeks to present these concerns as ones shared by many on the left and the right (309), Beever's politics are difficult to mistake - the desire to protect the individual from the overpowering collective; the belief that the foundations of political community are based on natural law; the view that private law should largely reflect those natural laws; the view that respect for 'traditional' private law is necessary (and perhaps sufficient) for a wellfunctioning society; the narrow and inegalitarian understanding of distributive justice; the concern that modern private law has been infiltrated by 'alien' public concerns, which in turn is but one manifestation of a more general encroachment of our freedoms by the state; the claim that people tend to over-rely on the state; the insinuation that seemingly innocuous Western welfare states already take us down the road to serfdom; even an opposition 
to the idea that people have any moral duty to rescue strangers ${ }^{40}$ - these are all familiar libertarian themes. ${ }^{41}$

Beever is entitled to his political opinions, but it would take a very different book from the one he has written to try to persuade those who do not share his views to adopt them. Since Beever does not argue for these views, I will not discuss here the merits or demerits of libertarianism. Absent a political argument, one would have expected at least some empirical evidence to support his prophecies of imminent doom. There are lots of sheep in New Zealand, but not, to my knowledge, any evidence that New Zealanders have become more sheep-like in their blind adherence to government or that they have forgotten their interpersonal relationships since they adopted their social accident compensation scheme. The US provides another example. Beever mentions it as a country where the distinction between public law and private law is not dominant (170), and with private law more politicised than elsewhere (251). ${ }^{42}$ On his analysis that must mean that the US is further down the totalitarian road than the rest of the common law world. There is, as far as I can tell, no evidence to support that.

The most comprehensive challenge to Beever's claims comes from the statistics mentioned earlier on the decline in human violence in exactly those times and places in which the state has been an active presence, a decline made all the more remarkable by the fact that population density is much higher now than in the past. The data themselves are overwhelming and difficult to dispute, but unless shown to be wrong, Beever would have to challenge the 
causal connection between the rise of the state and the decline of interpersonal violence. Doing so would present Beever with a dilemma: if the decline in violence can be attributed, even in part, to the state, then he is wrong to say that people 'overemphasize the state and overestimate its ability to facilitate justice' (309); quite the contrary, most people, perhaps because they are unfamiliar with the alternative, do not appreciate just how much the state is responsible for their peaceful lives. If on the other hand this decline has nothing to do with the state, then the most likely explanation is a major improvement in humans' concern for interpersonal relationships, which would suggest his worries are unfounded.

\section{CONCLUSION}

It is sometimes useful to take a step back from a theory, not just to point out its logical inconsistencies, hidden assumptions, or unwarranted conclusions, but in order to consider its overall message. Sometimes this more panoramic view can reveal what closer inspection misses out. When one does that, one of the striking features of Beever's position is just how strange it is. This is perhaps clearest in the position he takes towards the place of consequences. In contemporary moral philosophy a view is usually classified as non-consequentialist when its proponents think that consequences are not the only thing that matters, that sometimes other, 'deontological', considerations (sometimes called sideconstraints) override concern for consequences. What is remarkable about 
Beever's approach (along with that of other private law nostalgics) is that he thinks that in the domain of private law consequences never matter, that it is never right for humans to choose certain rules over others because they will improve their lot. Contrary to Beever's claim that this is the 'traditional' view that all philosophers used to accept and that this is the view that most people intuitively accept, this extreme view has very few adherents. ${ }^{43}$

Note again that even if one accepts that the foundations of political authority must be grounded in certain non-consequentialist moral considerations that just 'exist', that more concretely, the social contract is binding because of prepolitical, purely interpersonal norms, it in no way follows that contract law should simply imitate those norms. Nor does it follow that society may not choose other rules for its positive contract law, if it believes such rules could lead to better consequences. To think otherwise is to adopt a theological view of law, according to which True Private Law descends on us from heaven and what we need to do is 'discover... and develop...'(284) what it demands of us through conceptual or doctrinal analysis, and then follow. If doing so leads to consequences we find undesirable, well, dura lex, sed lex. This attitude is reflected in Beever's discussion of a wrongful life claim of a child born with 'catastrophic disabilities' (283). Beever argues that such a claim should be dismissed for the sole reason that 'she had no right not to have been born' (284). There is no recognition that there may be valid considerations in favour of imposing liability (better treatment in the future, concern for the plight of the family involved, preference for the innocent over the negligent, and, yes, 
also distributive justice) that are utterly ignored by the facile assertion regarding her rights. By relying on concepts developed when the technology that makes suchclaims possibledid not exist, Beever ignores all these considerations.

The practical effect of this view is that humans cannot change the law to fit their interests and changing environment, because, apparently, it is stronger than them. The only way to make sense of Beever's view is if he thinks that what (he thinks) commutative justice demands is the right decision, that all-things considered people in this child's situation, should not be compensated and that society would behave immorally towards someone if it forced him to pay damages in such a case. If this is so, then in presenting his arguments as 'conceptual', Beever tries to win a normative argument without bothering with a normative argument. If, as Beever says, commutative justice is a form of justice, it remains an open question whether we should try to have laws conforming to that form. Put differently, even if private law, properly understood, embodies the principles of commutative justice, it remains an open question whether we should have private law. These are the real, political, questions at stake between traditionalists and modernists. Forgotten Justice offers no assistance in answering them. 


\section{Notes}

1 N. J. McBride, 'Rights and the Basis of Tort Law' in D. Nolan and A. Robertson (eds), Rights in Private Law (Oxford: Hart Publishing, 2011) 331, 332. McBride models his story on A. MacIntyre, After Virtue: A Study in Moral Theory, (Notre Dame: Notre Dame University Press, 3rd ed, 2003). This is a rather odd choice for inspiration, as one of the ideas After Virtue is most famous for is that 'there are no such [things as natural or human] rights, and belief in them is one with belief in witches and in unicorns', ibid, 69. McBride, by contrast believes that the source of the present 'catastrophe' is forgetting that tort law is a matter of rights and duties.

2 See E. J. Weinrib, 'Does Tort Law Have a Future?' (2000) 34 Valparaiso U L Rev 561.

3 J. C. P. Goldberg and B. C. Zipursky, 'Torts as Wrongs' (2010) 88 Texas L Rev 917, 919.

4 R. Stevens, Torts and Rights (Oxford: OUP, 2007) 348. Admittedly, though unhappy about some developments in the '1970s and 1980s', ibid, 349, Stevens seems more content with present-day English tort law. But like other nostalgics, he is critical of much of contemporary tort scholarship. See ibid, 306-307.

5 A. Beever, Rediscovering the Law of Negligence (Oxford: Hart Publishing, 2007) 512-513, where Beever also mentions other aspects of the law that have been forgotten.

6 A. Beever, 'Our Most Fundamental Rights' in D. Nolan and A. Robertson (eds), Rights and Private Law (Oxford: Hart Publishing, 2012) 63, 87, n 82. Beever also says that a 'movement [that] propounds views inconsistent with interpersonal freedom ... is not genuinely liberal at all' (292).

7 See eg, J. Haidt, The Righteous Mind: Why Good People Are Divided by Politics and Religion (New York: Vintage, 2012) 16; L. Dumont, Essays on Individualism: Modern Ideology in Anthropological Perspective (Chicago: University of Chicago Press, 1986) 72-73 ('we have learnt to recognize by speaking of respectively traditional and modern views. For the ancients ... man is a social being ... For the moderns, under the influence of Christian and Stoic individualism, natural law, as opposed to positivelaw, does not involve social beings butindividuals...').

8 T. M. Scanlon, What We Owe to Each Other (Cambridge: Harvard University Press, 1998).

9 I used www.worldcat.org, that conducts a meta-search of the catalogues of most academic and reference libraries in the world.

10 For a discussion of this issue and a defence of the view Beever favours see L. Murphy, Institutions and the Demands of Justice' (1999) 27 Phil \& Pub Aff 251. Besides himself Murphy identifies Joseph Raz, G. A. Cohen, Robert Nozick (and pretty much all libertarians) as proponents of this view. These are not exactly unknown figures in contemporary political philosophy.

11 C. Fried, Contract as Promise (Cambridge: Harvard University Press, 1981) 36.

12 ibid, 16.

13 If I may be excused a personal note: a central theme of my tort law class, one that I repeat until my students are tired of hearing it, is that there are two ways of thinking of tort law. I call one of them the 'desert island view', according to which the basis for understanding tort law should be (roughly) the same for people who find themselves stranded on a desert island (ie, without any political community) as it is for us. I contrast this view with what I call 'the social welfare' approach. I do not hide the fact that I think the desertisland view is wrong, but Ido nothide the view from my students.

14 See P. Singer, The Expanding Circle: Ethics, Evolution, and Moral Progress (Princeton: Princeton University Press, new ed, 2011) especially 111-124.

15 See the Appendix to the longer version of this essay (mentioned in note * above), where I provide many examples in support of this claim.

16 See T. Hobbes, Behemoth, or the Long Parliament (Chicago: University of Chicago Press, 1990) dialogue 1.

17 The Appendix to the online version of this essay (see note * above) contains a longer discussion on Hobbes, which attempts to show why Beever is wrong to claim that Hobbes offers no reason for departing from the traditional view.

18 That in itself is another sense in which Beever's book ignores history, for one of the most dramatic developments in historiography to have taken place in the course of the last century has been the expansion of what counts as 'proper' history far beyond political history. See R. J. Evans, In Defence of History (London: Granta Books, new ed, 2000) 161-163.

19 See the statistics collected and discussed in S. Pinker, The Better Angels of Our Nature: Why Violence Has Declined (New York:Viking, 2011)chs 2-3. The data on declining homicide rates comefrom T. R. Gurr, 'Historical Trends in Violent Crime: A Critical Review of the Evidence' (1981) 3 Crime \& Justice 295. As Beever is so concerned about collective forgetting of interpersonal relationships, it is worth quoting from this essay: 'early estimates of homicide rates and their 
contemporary descriptions all sketch a portrait of a society in which men (but rarely women) were easily provoked to violent anger and were unrestrained in the brutality with which they attacked their opponents. Interpersonal violence was a recurring fact of rural and urban life', ibid, 307.

20 See the discussion on the decline in violence against women in Pinker, ibid, 394-415.

21 ibid, 121, 681. The thesis is associated with N. Elias, The Civilizing Process (Oxford: Blackwell, rev ed, 2000) 367-376, who suggests a causal link between the two.

22 On Bentham's views see L. C. Boralevi, Bentham and the Oppressed (Berlin: de Gruyter, 1984) ch 3; on Kant's see J. Finnis, 'Legal Enforcement of Duties to Oneself: Kant vs. Neo-Kantians' (1987) 87 Colum L Rev 433, 446-452.

23 J. Bentham, 'Essay on "Paederasty"' (part 2) (1978) 4 Journal of Homosexuality 91, 100-101. (This is a transcription of an unpublished manuscript written around 1785.)

24 Golberg and Zipursky, n 3 above, 917.

25 See I. Hacking, The Taming of Chance (Cambridge: CUP, 1990) chs 1-2; T. M. Porter, The Rise of Statistical Thinking 1820-1900 (Princeton: Princeton University Press, 1986) chs 1-3. On the slow reception of notions of probability and risk into commerce and insurance see L. Daston, Classical Probability in the Enlightenment (Princeton: Princeton University Press, 1988) 138-182.

26 (1928) 162 N.E. 99, 101. What exactly is the interpersonal relation in the heightened health risks from insufficient sleep? The only relation is that the studies that discovered this did this on the basis of the study of a large group of people who are otherwise completely unrelated.

27 See T. S. Kuhn, The Structure of Scientific Revolutions (Chicago: University of Chicago Press, 4th ed, 2012) chs 6-8.

28 For a different discussion of the problems with a corrective justice view of private law, both in general and with special focus on the law of unjust enrichment, see D. Priel, The Justice in Unjust Enrichment' (2014) 51 Osgoode Hall LJ (forthcoming), available at http://ssrn.com/ abstract $=2382784$.

29 This view is perfectly in line with Beever's political stance as it emerges from the book. See the discussion below.

30 Blackstone (and probably Kant as well) believed natural law sanctioned the former, Locke the latter. (Neither spoke of commutative justice in this context.) See W. Blackstone, Commentaries on the Laws of England (Oxford: Clarendon Press, 1765) ii, 13 ('the law of nature suggests, that on the death of the possessor, the estate should again become common ... unless otherwise ordered for the sake of civil peace by the positive law of society'); J. Locke, Two Treatises of Government (Cambridge: CUP, P. Laslett ed, 1988) 206-207, 210 (§§I.88-89, I.93) ('nature appoints the descendent of [parents'] Property to their Children, who thus come to have a Title, and natural Right of Inheritance to their Fathers Goods', quote from §I.89).

31 Calvin spoke of the 'natural rights of primogeniture'. See J. Witte, Jr, The Reformation of Rights: Law, Religion, and Human Rights in Early Modern Calvinism (Cambridge: CUP, 2007) 58. Locke explicitly rejected this view. See Locke, ibid, 210 (\$I.93).

32 One more sense in which the nostalgics' work yearns for bygone days is the extent to which it studiously ignores public law. Cf D. Priel, 'The Political Origins of English Private Law' (2013) 40 JL \& Soc 481, 501. Beever provides an excellent example: 'we do not go to court for [achieving distributive justice]. We go to court to have our rights vindicated' (306). This not only ignores most law, that these days does not originate in the courts (itself to a great extent a twentieth century development), but even much of the law that does. For a seminal discussion see A. Chayes, The Role of the Judge in Public Law Litigation' (1976) 89 Harv L Rev 1281.

33 Most famously R. C. Ellickson, Order Without Law: How Neighbors Settle Disputes (Cambridge, Mass: Harvard University Press, 1991) and L. Bernstein, 'Opting Out of the Legal System: Extralegal Contractual Relations in the Diamond Industry' (1992) 21 J Legal Stud 115. Both authors, by the way, make normative (and more specifically consequentialist) arguments in support of their claims. More generally, for the claim (from a libertarian) that law undermines interpersonal relationships see L. Ribstein, 'Law v. Trust'(2001) 81 BU L Rev 553.

34 For a clear example consider the diamond trade discussed in Bernstein, ibid.

35 Cf T. C. Schelling, The Strategy of Conflict (Cambridge: Harvard University Press, 1960) 43. This has interesting implications for the discussion on coercion in H. L. A. Hart, The Concept of Law (Oxford: OUP, 3rd ed, 2012) 27-28, but I will not explore them here.

36 See Beever, $\mathrm{n} 6$ above, 87. In response to such allegations it is worth noting that almost all the theorists whose ideas Beever thinks would be a bulwark against present-day horrors were supporters of humans being treated as property. Plato, Aristotle, Cicero, Aquinas, and Pufendorf (but not Kant) all endorsed slavery. Bentham, Sidgwick and virtually everyone in this age in which 'individuals are encouraged by the law to think of other individuals as resources to be used for their ends', ibid, reject it. 
37 Beever, $\mathrm{n} 6$ above, $87 \mathrm{n} 82$.

38 This makes for a nice contrast to communitarian complaints that modern liberals are responsible for the excessive individualism and soulless 'atomism' of our age. Liberals, it seems, can't win.

39 ibid, 86. Here Beever echoes the claim that the 'compensation culture', exemplified by an overly protective tort law and an exceedingly expansive liability of public authorities, can lead to moral decline. See Gorringev Calderdale Metropolitan Police [2004] UKHL 15, [2004] 1 WLR 1057 at [32]; Tomlinson v Congleton BC [2003] UKHL 47, [2004] 1 AC 46 at [81] ('The pursuit of an unrestrained culture of blame and compensation has many evil consequences and one is certainly the interference with the liberty of the citizen'). There is, however, little empirical evidence to support this claim. See R. Lewis et al, Tort Personal Injury Claims Statistics: Is There a Compensation Culture in the United Kingdom?' (2006) 14 Torts LJ 158.

40 'If [a drowning] child is not mine, then she has no rightagainst me that I rescue her'(272-273). 41 Beever complains that 'libertarian views fail sufficiently to acknowledge the need to protect interpersonal independence' (292). This, if I understand him, is the view that in protecting interpersonal freedom we must not neglect to protect it from attacks by other individuals, not just the state. But this is exactly in line with libertarian (as opposed perhaps to anarchist-libertarian) views. See R. Nozick, Anarchy, State, and Utopia (Oxford: Blackwell, 1974) 113-114. Details aside,

Beever's views are in line with the political underpinnings found in the work of other tort law nostalgics. See D. Priel, 'Torts, Rights, and Right-Wing Ideology'(2011) 19 Torts LJ 1.

42 Beever contrasts this to the rest of the common law world, where he claims this distinction is deeply ingrained. But this is a mistake: it is in fact a modern development, and as I argue elsewhere, it has been the product of politics, not any conceptual truth. See Priel, n 33 above.

43 See O. Johansson-Stenman, 'Are Most People Consequentialist?' (2012) 115 Economic Letters 225; J. Greene, 'The Secret Joke of Kant's Soul' in W. Sinnott-Armstrong (ed), Moral Psychology: Volume 3, The Neuroscience of Morality (Cambridge, Mass: MIT Press, 2008) 35. One need not endorse Greene's normative conclusions to accept his empirical findings about the place of consequences in moral reasoning. 